\title{
Note on Terms
}

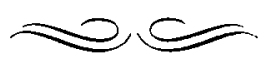

In THOSE SECTIONS of the book devoted to close textual analysis, my descriptions of specific shots rely (for reasons of space) on notational acronyms designating camera distance and angle that have become widely used in cinema studies. They include the following:

ECU extreme close up

CU close up (the shot of a face or object)

MCU mid close up (the shot of a person from the chest up)

MS mid shot (the shot of a person from the waist up)

AS "American shot" (the shot of a person from the knees up)

FS full shot (the shot of a person from the feet up)

LS long shot

ELS extreme long shot

HA high angle (a shot taken from above eye level, looking down)

LA low angle (a shot taken from below waist level, looking up)

When a film's mise-en-scène combines two or more planes of interest within the frame, I use a double acronym, such as MS/LS or even HA MS/LS. Only one other acronym appears frequently-POV, for point-of-view shot.

In referring to specific films throughout the book, I use the French title circulated at the time of the film's release in France. When the French title is unknown or uncertain, I use the English title given for the film's release in the United States or England. 
